\title{
Leucine-rich glioma-inactivated protein 1 antibody encephalitis
}

\author{
A case report
}

OPEN

Yunis Mayasi, MD

Deepak Takhtani, MD

Neeta Garg, MD

Correspondence to

Dr. Garg:

Neeta.Garg@umassmemorial.org

\section{ABSTRACT}

Objective: To describe a case of leucine-rich glioma-inactivated protein 1 (LGI1) antibody-associated encephalitis.

Methods: The clinical and ancillary data and brain MRIs were gathered retrospectively by chart review. Relevant literature on similar cases was also reviewed.

Results: The diagnosis of LGI1 antibody-associated autoimmune encephalitis was based on the typical clinical presentation of seizures, psychiatric symptoms, and memory loss as well as negative diagnostic testing for cancer; the diagnosis was confirmed by positive LGI1 antibody. The patient responded favorably to treatment with IV immunoglobulin and continues to do well.

Conclusion: LGI1 antibody-associated encephalitis has increasingly been recognized as a primary autoimmune disorder with good prognosis and response to treatment. Neurol Neuroimmunol Neuroinflamm 2014;1:e51; doi: 10.1212/NXI.0000000000000051

\section{GLOSSARY}

AMPA $=\alpha$-amino-3-hydroxy-5-methyl-isoxazoleproionic acid; Caspr2 $=$ contactin-associated protein-like 2; GABA $_{\mathbf{B}}=$ $\gamma$-aminobutyric acid B; HSV = herpes simplex virus; Ig = immunoglobulin; IVIg = IV immunoglobulin; LE = limbic encephalitis; LGI1 = leucine-rich glioma-inactivated protein 1; NMDA = N-methyl-d-aspartate; VGKC = voltage-gated potassium channel.

Limbic encephalitis (LE) has traditionally been described as a paraneoplastic syndrome associated with onconeural antibodies induced by the neoplasm and directed against intracellular antigens, with the usual clinical presentation of subacute dementia, seizures, and psychiatric disturbances. ${ }^{1-3}$ A distinct group of autoimmune encephalitis not associated with malignancy and with antibodies targeting extracellular antigens has recently been recognized and termed neuronal surface antibody syndrome or autoimmune synaptic encephalitis. ${ }^{3-6}$ These neuronal surface antibodies target the neuronal cell surface or synaptic proteins, including NMDA, $\alpha$-amino3-hydroxy-5-methyl-isoxazoleproionic acid (AMPA), and $\gamma$-aminobutyric acid B (GABA $)$ receptors. $^{7,8}$ Leucine-rich glioma-inactivated protein 1 (LGI1) and contactin-associated protein-like 2 (Caspr2) have recently been identified as specific target proteins in most cases of autoimmune encephalitis previously believed to be associated with antibodies against voltagegated potassium channel (VGKC) complex. ${ }^{9,10}$ We describe a case of LGI1 antibody-associated encephalitis with excellent response to immunotherapy.

CASE REPORT A 62-year-old Caucasian man who was diagnosed with REM sleep behavior disorder 6 months prior to presentation presented with new-onset complex partial with secondary generalized seizures without any associated systemic or other neurologic symptoms. This was followed by progressive cognitive decline and psychiatric symptoms including depression, anxiety, and paranoia within 2 months. The neurologic examination was consistent with dementia without any focal motor or sensory deficits. He underwent extensive diagnostic workup, which was unrevealing for any apparent etiology. The routine laboratory studies were normal except for persistent hyponatremia. The serologic tests for systemic infection, including peripheral CD4 count, serum HIV 1 and 2 and human T lymphotropic virus 1 and 2

From the Departments of Neurology (Y.M., N.G.) and Radiology (D.T.), University of Massachusetts Medical School, Worcester, MA. Go to Neurology.org/nn for full disclosures. Funding information and disclosures deemed relevant by the authors, if any, are provided at the end of the article. The Article Processing Charge was paid by the Department of Neurology, University of Massachusetts Medical School.

This is an open access article distributed under the terms of the Creative Commons Attribution-Noncommercial No Derivative 3.0 License, which permits downloading and sharing the work provided it is properly cited. The work cannot be changed in any way or used commercially. 
antibodies, hepatitis panel, syphilis immunoglobulin (Ig) G antibody, Mycobacterium tuberculosis antigen lymphocyte stimulation assay, Aspergillus antigen and antibody, and urine Legionella antigen screen, were all negative. A serum autoantibody panel showed only mild elevation of anti-RNP antibody at 2.3 units antibody index (normal $<1$ antibody index).

CSF analysis revealed slightly elevated protein level of $50 \mathrm{mg} / \mathrm{dL}$ (normal range $15-45 \mathrm{mg} / \mathrm{dL}$ ), normal cell count and glucose level, and sterile bacterial and fungal cultures. Screening for herpes simplex virus (HSV) 1 and 2; enterovirus, varicella-zoster virus, and John Cunningham virus by PCR; Borrelia burgdorferi antibody; and Venereal Disease Research Laboratory was negative. Oligoclonal bands in CSF were not detected. The IgG index was elevated at 0.74 (normal range $0.28-0.66$ ). HSV $2 \mathrm{IgG}$ antibody level was elevated at 1.52 index value (normal range $<0.89$ index value). HSV 1 and $2 \mathrm{IgM}$ antibodies were negative.

Brain MRI showed minimally increased signal in the cortices of the medial temporal lobes (figure, A) beside nonspecific white matter T2 hyperintensities on the fluid-attenuated inversion recovery sequence (figure, B). EEG showed diffuse slowing of background rhythm. A 4-vessel cerebral angiogram showed normal intracranial and extracranial vasculature. Leptomeningeal and cortical (right frontal) biopsy was also obtained; the histology showed no evidence of vasculitis, inflammation, infection, neoplasm, or any other pathologic process within the dura, arachnoid, or cortex.

The patient's clinical condition continued to decline, with worsening cognitive function and psychiatric symptoms including confusion, agitation, paranoid behavior, and aggression. He continued to have recurrent generalized seizures despite being on optimal dosage of multiple antiepileptic medications.

\section{Figure Brain MR}
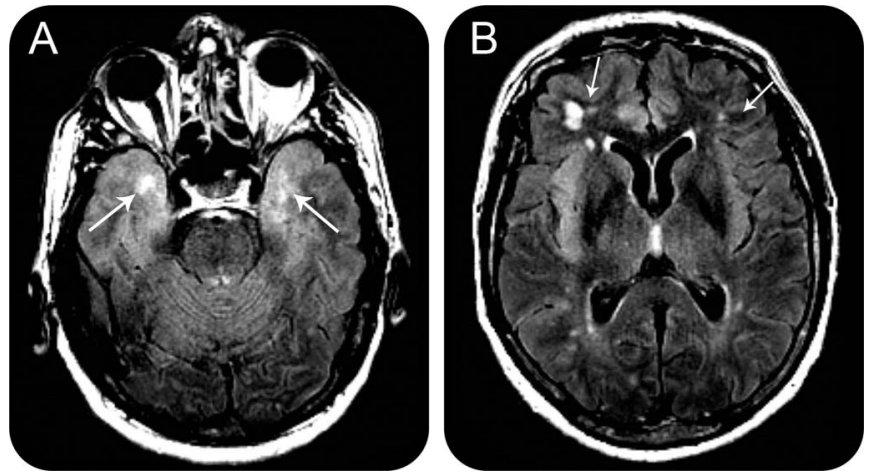

Brain MRI axial fluid-attenuated inversion recovery (FLAIR) image shows ill-defined increased signal in the medial temporal lobes bilaterally (A). Axial FLAIR slice through the basal ganglia demonstrates multiple other nonspecific white matter T2 hyperintensities (B).
He was empirically treated with high-dose IV glucocorticoids with no significant clinical improvement.

Given the clinical presentation of progressive encephalopathy syndrome with worsening neuropsychiatric symptoms and refractory seizures, the diagnosis of LE was considered and further diagnostic testing was undertaken in search of occult systemic malignancy. CT scan of chest, abdomen, and pelvis did not reveal any evidence of cancer. Scrotal Doppler ultrasound showed a right testicular mass lesion suspected to be neoplasm, which on biopsy was found to be a focal parenchymal infarction. At this point, the diagnosis of nonparaneoplastic LE was suspected and the screening test for VGKC-complex antibody using radioimmunoassay showed an elevated level of $688 \mathrm{pmol} / \mathrm{L}$ (normal range $<450 \mathrm{pmol} / \mathrm{L}$ ). Additional testing for LGI1 and Caspr2 antibody by indirect immunofluorescence staining (cell-based assay) showed positive LGI1 antibody and negative Caspr2 antibody.

The patient was subsequently treated with a 5-day (400 mg/kg/day) course of IV immunoglobulin (IVIg). He had excellent clinical response to IVIg treatment, with resolution of seizures and psychiatric symptoms. His mental status and cognitive function improved to his premorbid baseline within a few weeks. Currently, the patient is receiving maintenance IVIg treatment $(200 \mathrm{mg} / \mathrm{kg})$ every 3 months. He continues to do well clinically, independently performing his activities of daily living.

DISCUSSION Our case demonstrates the importance of high suspicion for LGI1 antibody-induced LE in a patient with seizures and rapidly progressive dementia because these patients respond remarkably well to IVIg. Our patient underwent extensive investigation including brain biopsy that would have been avoided with an early diagnosis of autoimmune LE.

LE is a group of immune-mediated disorders that encompasses the classic paraneoplastic encephalitis syndromes that are associated with onconeural antibodies directed against intracellular (nuclear or cytoplasmic) antigens and the more recently described nonparaneoplastic autoimmune encephalitides that are mostly associated with antibodies against extracellular (neuronal cell surface or synaptic) antigens. ${ }^{3,5-7}$ The antigens in cases of nonparaneoplastic autoimmune LE include VGKC complex, NMDA, AMPA, glycine, or $\mathrm{GABA}_{\mathrm{B}}$ receptor. ${ }^{2,7,10-12}$ The initial reports suggested that the antibodies against VGKC complex bind Kv1.1 and Kv1.2; however, the recent studies have shown LGI1 and Caspr2 to be the specific targets. ${ }^{9}, 10,13,14$ Typical clinical presentation of LE associated with LGI1 antibody includes cognitive decline, behavioral disturbance, and seizures. ${ }^{9,10}$ The clinical 
presentation in our case was fairly typical, with dementia, psychiatric symptoms, and seizures. The other specific clinical features seen in patients with LGI1 encephalitis include faciobrachial dystonic seizures, which can precede the other classic symptoms of LE, ${ }^{14,15}$ and hyponatremia. ${ }^{10,14}$ Our patient did not have the typical faciobrachial dystonic seizures, but he did present with the characteristic hyponatremia. The brain MRI in LGI1 antibody encephalitis cases may be normal or show increased T2 signal in bilateral temporal lobes, as was seen in our patient. ${ }^{14,15}$ Most cases of LGI1 encephalitis are nonparaneoplastic; the diagnosis of LGI1 encephalitis in our case was established by positive LGI1 antibody in the absence of systemic malignancy.

Patients with encephalitis associated with antibodies to cell surface and synaptic antigens, such as LGI1 encephalitis, respond better to immune-based therapies due to the direct pathogenic role of these autoantibodies, in contrast to the cases with antibodies directed against intracellular antigens such as $\mathrm{Hu}$ proteins or Ma 2, which are believed to cause T-cellmediated neuronal degeneration that responds poorly to immune-based therapies. ${ }^{3,5,7,14}$ LGI1 is a glycoprotein secreted from presynaptic terminals that binds to presynaptic disintegrin and metalloproteinase domain-containing protein 23 (ADAM23) and postsynaptic ADAM22 and plays an important role in synaptic transmission by regulating the presynaptic Kv1.1 and Kv1.2 subunits and AMPA receptors. ${ }^{5,10}$ LGI1 antibodies may prevent binding of LGI1 to the receptors it regulates, disrupt currents mediated by $\mathrm{Kv} 1.1$ and Kv1.2, and impair AMPA receptor function. ${ }^{5}$ The pathogenic role of LGI1 antibodies is supported by observed clinical improvement with immunotherapy in most of these cases. ${ }^{8,14,15}$ Combination immunotherapy with steroids and IVIg may be superior to monotherapy with either agent alone with less relapse risk, although these observations are based on experience in small case series. ${ }^{14}$ The clinical improvement following IVIg treatment in our patient supports the notion of the pathogenic role of LGI1 antibodies.

We present a case that highlights the importance of early screening for LE in a patient presenting with relatively rapidly progressive cognitive decline and seizures with no clear etiology. As an increasing number of autoimmune nonparaneoplastic LE cases are being recognized, it is important to screen patients with suspected LE for the presence of neuronal surface antibodies, including LGI1 antibodies, in addition to conducting a search for systemic malignancy. Early diagnosis and treatment with immunotherapy such as IVIg can lead to rapid resolution of clinical symptoms in these patients.

\section{AUTHOR CONTRIBUTIONS}

Yunis Mayasi: data acquisition, literature search, manuscript preparation and review. Deepak Takhtani: acquisition and review of images, manuscript review. Neeta Garg: concept, literature search, acquisition and review of clinical data, manuscript preparation and editing.

\section{STUDY FUNDING}

No targeted funding reported.

\section{DISCLOSURE}

The authors report no disclosures. Go to Neurology.org/nn for full disclosures.

Received July 12, 2014. Accepted in final form October 8, 2014.

\section{REFERENCES}

1. McKeon A. Paraneoplastic and other autoimmune disorders of the central nervous system. Neurohospitalist 2013; 3:53-64.

2. Dalmau J, Rosenfeld MR. Paraneoplastic syndromes of the CNS. Lancet Neurol 2008;7:327-340.

3. Graus F, Saiz A, Dalmau J. Antibodies and neuronal autoimmune disorders of the CNS. J Neurol 2010;257: 509-517.

4. Lancaster E, Martinez-Hernandez E, Dalmau J. Encephalitis and antibodies to synaptic and neuronal cell surface proteins. Neurology 2011;77:179-189.

5. Lancaster E, Dalmau J. Neuronal autoantigens-pathogenesis, associated disorders and antibody testing. Nat Rev Neurol 2012;8:380-390.

6. Ramanathan S, Mohammad SS, Brilot F, Dale RC. Autoimmune encephalitis: recent updates and emerging challenges. J Clin Neurosci 2014;21:722-730.

7. Bien CG, Vincent A, Barnett MH, et al. Immunopathology of autoantibody-associated encephalitides: clues for pathogenesis. Brain 2012;135:1622-1638.

8. Vincent A, Buckley C, Schott JM, et al. Potassium channel antibody-associated encephalopathy: a potentially immunotherapy-responsive form of limbic encephalitis. Brain 2004;127:701-712.

9. Irani SR, Alexander S, Waters P, et al. Antibodies to Kv1 potassium channel-complex proteins leucine-rich, glioma inactivated 1 protein and contactin-associated protein- 2 in limbic encephalitis, Morvan's syndrome and acquired neuromyotonia. Brain 2010;133:2734-2748.

10. Lai M, Huijbers MG, Lancaster E, et al. Investigation of LGI1 as the antigen in limbic encephalitis previously attributed to potassium channels: a case series. Lancet Neurol 2010;9:776-785.

11. Lancaster E, Lai M, Peng X, et al. Antibodies to the GABA(B) receptor in limbic encephalitis with seizures: case series and characterisation of the antigen. Lancet Neurol 2010;9:67-76.

12. Lai M, Hughes EG, Peng X, et al. AMPA receptor antibodies in limbic encephalitis alter synaptic receptor location. Ann Neurol 2009;65:424-434.

13. Alcantara M, Bennani O, Verdure P, Lepretre S, Tilly H, Jardin F. Voltage-gated potassium channel antibody paraneoplastic limbic encephalitis associated with acute myeloid leukemia. Case Rep Oncol 2013;6:289-292.

14. Shin YW, Lee ST, Shin JW, et al. VGKC-complex/LGI1antibody encephalitis: clinical manifestations and response to immunotherapy. J Neuroimmunol 2013;265:75-81.

15. Irani SR, Michell AW, Lang B, et al. Faciobrachial dystonic seizures precede Lgi1 antibody limbic encephalitis. Ann Neurol 2011;69:892-900. 


\title{
Neurology \\ Neuroimmunology \& Neuroinflammation
}

\author{
Leucine-rich glioma-inactivated protein 1 antibody encephalitis: A case report \\ Yunis Mayasi, Deepak Takhtani and Neeta Garg \\ Neurol Neuroimmunol Neuroinflamm 2014;1; \\ DOI 10.1212/NXI.0000000000000051
}

This information is current as of December 11, 2014

\section{Updated Information \& Services}

References

Subspecialty Collections

Permissions \& Licensing

\section{Reprints}

including high resolution figures, can be found at:

http://nn.neurology.org/content/1/4/e51.full.html

This article cites 15 articles, 0 of which you can access for free at: http://nn.neurology.org/content/1/4/e51.full.html\#\#ref-list-1

This article, along with others on similar topics, appears in the following collection(s):

Autoimmune diseases

http://nn.neurology.org//cgi/collection/autoimmune_diseases

Encephalitis

http://nn.neurology.org//cgi/collection/encephalitis

Information about reproducing this article in parts (figures,tables) or in its entirety can be found online at:

http://nn.neurology.org/misc/about.xhtml\#permissions

Information about ordering reprints can be found online:

http://nn.neurology.org/misc/addir.xhtml\#reprintsus

Neurol Neuroimmunol Neuroinflamm is an official journal of the American Academy of Neurology.

Published since April 2014, it is an open-access, online-only, continuous publication journal. Copyright $(0$ 2014 American Academy of Neurology. All rights reserved. Online ISSN: 2332-7812.

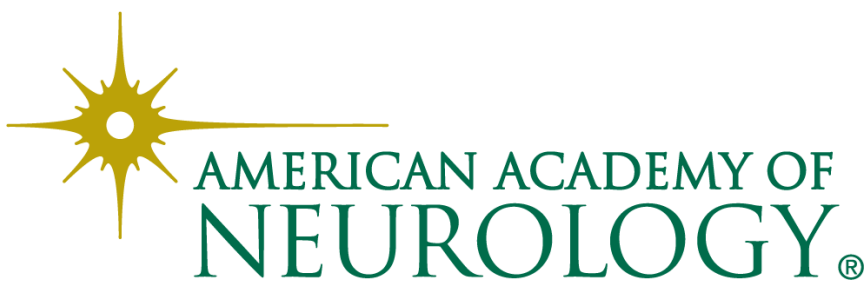

